\title{
Institutional Design of the Regulator in Latin America and the Caribbean
}

\author{
Jorge Dussán Hitscherich \\ UNIVERSIDAD DEL ROSARIO, COLOMBIA \\ Juan Manuel Roldán Perea \\ UNIVERSIDAD DE LOS ANDES, COLOMBIA
}

\begin{abstract}
A direct relationship between democracy and development shows that the most fair and equal societies are the ones in which citizens have access to political and economic decision-making centers, through a legal system that guarantees the full exercise of their rights and the possibility of demanding accountability from the authorities for the trust deposited in them by the community. This is even more important when referring to poor people living in cities and rural areas. For them, the public sector -with all its structural deficits and problems- does not acknowledge their needs, and the lack of real solutions for the communities leads to an alarming and constant social tension, which affects governability in our countries. This paper establishes the need for a change in the institutional model of the telecom regulators, aiming for more efficient regulations that address citizen's needs, especially the poorest sectors, through an increase in citizen's participation in decisions affecting them.
\end{abstract}


This paper establishes the need of a change in the institutional model of the telecom regulator, aiming to direct the regulation more effectively to address people's needs, especially the poorest sector, through increased citizen's participation in the decisions affecting them. Unlike other studies, this document does not refer to the institutional endowment, the relationship among the regulator and other agencies, or the description of the regulatory models that could be applied. ${ }^{1}$ The thesis presented in this work aims at allowing consumers to participate in order to improve the regulatory system. ${ }^{2}$ With that same purpose, a survey was designed for authorities, consumers and companies, in order to obtain statistical data to measure the effectiveness of the current mechanisms for consumer participation and the main obstacles to exercise that right. Using that information, the objective is to elaborate some recommendations that could guarantee an efficient regulatory model for consumers, in addition to revising the institutional foundations and other aspects mentioned before.

It should be taken into account that, in addition to the advantages that usually result from citizen's participation in the decisions affecting them, most of the countries in the region have already completed an initial "pro-competition" regulatory cycle, which focused on the rebalancing of tariffs, the prohibition of cross-subsidies, the privatization of trusts, the removal of entry barriers and the application of interconnection rules, among other aspects. Yet new rules need to be developed to further consumers' rights in an effective way, to reduce the risk of regulatory capture, and to make regulators aware of citizens' interests and be accountable to them for the decisions they make, prioritizing the poorest and weakest sectors.

\section{Institutional Design of the Regulator}

In order to support the privatization processes that took place during the last decade in almost all Latin America, telecom regulators were designed to balance investors' interests. Their purpose was to prevent capital from being caught in the usual political changes in the continent ${ }^{3}$, and at the same time to seek the fulfillment of the fol-

\footnotetext{
${ }^{1}$ (Levy \& Spiller, 1993, p. 6).

2 "Consumer" is not only the person who receives a service or purchases a good, but also the individual who demands the service, even when he/she is not able to purchase or receive it at a certain moment. In the telecommunications sector, it is common to identify the "consumer" with the "user" of the services. For example, the Directive 97/33/CE of the European Parliament and of the Council of 30 June, 1997 defines users as "people, including consumers, or the entities which use or request public use telecommunications services."

${ }^{3}$ It is worth-noting, for example, that when Peru sold its state operator to Telefónica, the contract was approved by the legislative body of that country. With that action, its current owners ensured that the conditions offered would not be changed. However, it is uncommon that an act that is naturally inter partes, is executed by a law that should be of general nature or erga omnes. The result is that the regulator has a very narrow margin to defend consumers, such as the application of a flat fee for Internet access or to foster competition.
} 
lowing objectives: Increased coverage, improved service quality and reduced fees, while directing market forces to cover the basic needs of the poorest sectors. ${ }^{4}$

That is how regulators have assumed that their main task is to promote competition, in order to improve service supply and improve consumers' welfare. ${ }^{5}$ However, many sectors of the population are left outside pure market solutions. Unfortunately, the urge to continue moving on with the privatizations did not allow for a clear definition of the functions to be fulfilled by the regulatory commissions in order to solve such inequalities, nor the instruments to be used for that purpose ${ }^{6}$. In fact, in most of Latin American and Caribbean countries, universal service policies and their financing developed after privatization and liberalization processes took place, as it is shown in the following table. ${ }^{7}$

Table 1: Market Reforms in Latin America

\begin{tabular}{|l|c|c|c|c|}
\hline \multicolumn{1}{|c|}{ Country } & $\begin{array}{c}\text { Year of } \\
\text { Privatization }\end{array}$ & $\begin{array}{c}\text { Year the } \\
\text { Regulatory Agency } \\
\text { was created }\end{array}$ & $\begin{array}{c}\text { Year the } \\
\text { Universal Program } \\
\text { was created }\end{array}$ & $\begin{array}{c}\text { Universal } \\
\text { Service Fund }\end{array}$ \\
\hline Argentina & 1990 & 1996 & 2000 & 2000 \\
\hline Bolivia & 1995 & 1994 & 2001 & 2001 \\
\hline Brasil & 1998 & 1997 & 1994 & 2000 \\
\hline Chile & 1988 & 1994 & 1999 & 1994 \\
\hline Colombia & NA & 1994 & 2000 & 1994 \\
\hline Costa Rica & NA & 1996 & 2000 & 2000 \\
\hline Ecuador & NA & 1995 & 1998 & 2000 \\
\hline El Salvador & 1998 & 1996 & 1996 & 1998 \\
\hline Guatemala & 1998 & 1996 & 2002 & 1996 \\
\hline Mexico & 1990 & 1996 & 1995 & 2002 \\
\hline Paraguay & NA & 1995 & 1993 & 1995 \\
\hline Peru & 1994 & 1994 & 2000 & 1993 \\
\hline Venezuela & 1991 & 1991 & & 2000 \\
\hline
\end{tabular}

Source: Jordana and Sancho (2000); and author's data.

\footnotetext{
4 "We have provided evidence as to the importance of Jamaica's political structure in the development of regulatory institutions and on their performance implications. A major result is that given the nature of Jamaica's parliamentary system, with a strong two-party system, with very little independence among individual members of parliament, decentralized decision making based on strong -statutory based- procedural requirements may not provide the necessary regulatory stability to promote private sector investment in sectors characterized by sunk investments and domestic consumption." Sampson y Spiller 1994, p. 53. There is also ample evidence on this issue in Stiglitz (2002).

${ }^{5}$ See Ariño (2004) and Intven (2000).

${ }^{6}$ See Kessides (2004).

${ }^{7}$ It should be noted that before having a universal service policy, there was a regulation in place that
} 
On the other hand, the problem of service access by the poorest sectors, by people living in rural areas and other groups such as disabled individuals or ethnic minorities is reduced to carrying out universal access programs ${ }^{8}$, which are designed without the participation of the people involved. Therefore, it is necessary to set up conditions to make these groups foster action on the regulator's part and become leaders to find their own solutions. In addition, the consumer relationships that arise from privatization and consolidation as markets mature, require to take into account the need of establishing wider and more effective mechanisms to protect consumers. Due to these reasons, different countries have introduced changes in their legal organizations. Some of these changes are described below.

\section{The Consumer Ombudsman}

If the first right of the consumers is to receive a good quality service, the second right should be to make complaints due to bad service. However, it is a mistake to think that all consumers know their rights. Although many legal systems include the possibility of making complaints about public utilities, especially about bills, a timely and adequate answer to the consumer demands is not guaranteed.

On the contrary, the numerous and dispersed rules, the lack of knowledge to use legal actions and resources, the time and effort that they demand, the difficulty to fulfill the formalities required in some cases, the number of complaints, the little amount of money the complaint may imply, the delay in the solution of the dispute, the lack of control from the authorities, and the lack of options to choose other suppliers, discourage consumers from exercising this right. Thus, it is common to observe a passive attitude in consumers, which leads to an implied authorization to forget the rules that protect them. ${ }^{9}$

forced service companies to achieve goals that benefited underprivileged sectors, e.g. to achieve a telephone density level, to install a certain number of public telephones or to provide service at affordable prices through cross-subsidies.

${ }^{8}$ In telecommunications, universal service programs refer to social telecommunication projects, which can be directed to "universal access" or "universal service" goals. In that sense, "universal service" is the minimum set of services, of a certain quality, available to any user, independently of his/her geographic location and, taking into account the specific national conditions, at an affordable price (Directive 2002/21/CE and Directive 2002/22/CE. It can also be found in the "Greenbook on Services of General Interest" of the Commission of the European Communities, p. 17). This set of services must be available in each household. Universal access refers to the right any person has to use a telecommunications service, initially a telephone but with the possibility of using other services such as a fax or Internet, at a community access point. Community access projects plan one community access point for a certain population density (for example, a telephone for locations with 500 inhabitants), or an access point at a certain distance.

${ }^{9}$ Perez-Bustamante (2004). 
Summarizing, the proliferation of mechanisms in the legal system does not guarantee consumers' rights. On the contrary, it results in tiresome proceedings and an increase in administrative and legal steps that must be taken, which represent a high burden for the State. Because of this, some countries have alternative mechanisms, such as the Ombudsman or consumer advocate, whose mission is to foster the fulfillment of the norms that govern the service and to improve the relationships between the companies and the consumers, by being involved in solving complaints, seeking the adoption of fair decisions and offering solutions in the general interest. To do so, the Ombudsman must have instruments that guarantee his/her independence, fairness and trust from the public, acting as a source of information and promoting change in the companies. ${ }^{10}$

According to a review of the development this mechanism has had in different countries and economic sectors, the Ombudsman or consumer advocate may have the following origin: ${ }^{11}$

a) Individual Advocacy. Created by a company to deal exclusively with matters involving them and their clients. This is the case of the Reader's or Television Viewer's Ombudsmen that has become common in the media and other industries or economic sectors such as the financial one.

b) Joint or Decentralized Advocacy. Created by a union or corporation; affiliated companies and their customers have access to it. This is the case of the Office of the Telecommunications Ombudsman (OTELO) in the United Kingdom, a non profit association of telecommunication services providers, including electronic communications public networks providers, public electronic communication services providers and people who offer facilities associated to a public network of electronic communications or a public service of electronic communications ${ }^{12}$.

c) Mixed Advocacy. It has a legal origin, and the authorities were summoned to participate in its formation. This is the case of the Ombudsman in the Telecommunications Industry Ombudsman (TIO) in Australia, a non-government, non-profit organization made up of telephone and Internet service

\footnotetext{
${ }^{10}$ Commission of the European Communities, Recommendation 98/257/CE.

${ }^{11}$ Benetti (2001).

${ }^{12}$ OTELO reviews the complaints about services and/or products provided to residential users and small businesses under the OFCOM jurisdiction and makes sure the solutions adopted are accomplished by the telecommunications companies. Small businesses users are those that spend 5,000 pounds per year of service and those businesses that, in spite of spending more than 50,00 pounds per year, have 10 employees or less.
} 
companies, as a free and independent alternative dispute resolution scheme for small business and residential consumers who have a complaint about their telephone or Internet service. In fact, what is known as TIO is a complex organization, established by the Australian Federal Government in 1993 and then acknowledged by the Telecommunications Act in 1997. It is made up of a Council, a Board of Directors and by the Telecommunications Industry Ombudsman. The Board is responsible for the administrative management, while the Council appoints the Ombudsman and designs the organization policies and maintains its independence. The Council is made up of service provider representatives and consumer delegates. There are three more consumer delegates than industry representatives.

\section{Public Hearings and Control}

The citizens' participation in the management of public utilities is not limited to the advocacy of the consumer rights before the companies. However, even when many countries recognize in their legislation the citizens' rights to participate in the decisions that affect them, it is very uncommon for people to become involved with the administrative responsibilities and even rarer that the officials pay attention to their opinions when making decisions.

Therefore, even when some regulators formally fulfill a process of public discussion for regulation projects, in many cases the opinions presented are not taken into account and there is nothing to force the organizations to answer the comments received. So, in practice, no advances are made regarding the disadvantages previously mentioned. Some countries, however, have improved the regulation elaboration process, clearly stating the regulator's responsibility before the consumers.

\section{A. USA}

To make a decision, the Federal Communications Commission (FCC) issues three publications (NOI or Notice of Inquiry, NPRM or Notice of Proposed Rulemaking and FNPRM or Further Notice of Proposed Rulemaking) in order to receive and review the comments of the interested parties in each opportunity. After the comments have been considered, the FCC publishes a report (R\&O or Report and Order) with the new regulations, or decides not to proceed. Summaries of these reports are published in the Federal Register. If for any reason a person is not satisfied, he/she may submit a reconsideration request within 30 days after the day the report is issued. To answer the reconsideration request, the FCC issues a memorandum (MO\&O or Memorandum Opinion and Order). If is decides to issue a regulation, it publishes a 
public notice (PN or Public Notice) indicating the date it intends to begin its enforcement. Many of the important regulations are decided in meetings open to the public, in which FCC commissioners discuss and vote. These meetings are announced, together with the issues to be treated, seven days in advance in the FCC's Web site.

\section{B. CANADA}

The Canadian Radio-television Telecommunications Commission communicates its intention to initiate a discussion process in its Web site and in the Canada Gazette. In addition, it may send invitations to specific groups and rural communities to participate by publishing newspaper announcements or by sending invitations with service bills, if addressed to the users.

The regulation may be discussed in a public hearing, usually when it refers to applications for new broadcasting licenses, to matters related to amendments to regulations or to a proceeding that the agency considers important. Anyone may take part in these hearings, as long as it submits his/her comments in writing.

\section{PERU}

The Organization for the Supervision of Private Investments in Telecommunications (OSIPTEL) must publish the general scope rules drafts so any interested person may participate. To do so, OSIPTEL must carry out hearings in different cities, previously announced in various media. In addition, it organizes seminars, issues publications and, in general, offers information to the public about the telecommunications sector, mainly through sharing information regarding consumers' rights through OSIPTEL's Users Management bureau, a department that assesses regulatory impact.

\section{COLOMBIA}

Even when the Telecommunications Regulatory Commission (CRT) was not obliged to make consultations about its regulatory projects, in 1997 the agency created an internal policy that mandated publishing on its Web site the relevant studies and drafts of the rules to be adopted, in order to receive comments from all interested parties. The presidential decree 2696 of 2004 made the CRT policy compulsory for all public uyility regulators (CRA for the water and sanitation system, and CREG for the energy and gas sectors). The decree required answering the comments received and publishing a document explaining the regulator's position regarding each one of them. In addition, the regulatory commissions are forced to have a five years strategic plan and a regulatory agenda indicating the projects to be carried out each year. The draft of the agenda must be publicly discussed before its approval. 
When the regulation refers to fixed telephone services fees under a special regime as residential public utility services, the CRT must present the studies based on which the fees will be set one year in advance, and partial results must also be published. Three months before the scheduled date for the fees to enter into effect, the methodology and formulas, the studies, and the texts of the resolution (with an explanatory document) must be published in the CRT website. These documents are also sent to the Governors, who are the political-administrative heads of the second level territorial entities (departments) in order to be disseminated.

In addition, the regulatory commissions must organize public hearings in different districts and municipalities to foster users' involvement, who must be summoned 10 days in advance via different media. Hearings are recorded and a report of the discussion must be written. Public consultations, comments, information, studies and proposals made during this process are used to elaborate a document explaining the reasons for accepting or rejecting the proposals.

\section{User Groups}

A recent study states that the privatization of the telecommunication companies in Chile, Argentina and Brazil were the outcome of decisions made by the governments, against the people's will. ${ }^{13}$ On the contrary, in those countries where there were public consultation processes about company privatization, such as Costa Rica and Paraguay, citizens rejected the proposal. Likewise, many Latin American consumer organizations appeared simultaneously with the privatizations of the state companies, mainly as a reaction against the increase in fees and the removal of subsidies.

\footnotetext{
13 "Institutional factors such as the nature of political parties and the level of prior state organization of consumers largely determined the repertoires of contention available to consumer movements after privatization. Under the leadership of politicians and activists, Argentine consumers engaged in highly contentious collective action. They refused to pay telephone bills in protest of higher fees and organized boycotts of telephone service.". Later on it adds: “The advocates of privatization generally have ignored the importance of a political voice for consumer advocacy in Latin American countries. Economic studies that do mention consumer involvement warn that any changes in policy might result in accusations that the government was retracting its commitments to business. Many political economists and business specialists seem to view the participation of consumers and consumer advocates in regulatory decisions as unnecessary politicization of technical policy arenas. Some political scientists even consider the expression of discontent through social movements to be generally disruptive and undesirable in new democracies. Others view political protest generally as a positive thing, but distrust the idea of consumer protection, or "consumerism," as a mobilizing factor.

Most political scientists and economists, as well as politicians and policy activists, agree that new stakeholders in economic reforms must be created for such reforms to be sustained politically. Yet, while consumers would appear to be among the most obvious potential beneficiaries of reform, most analysis of privatization rarely identify consumers explicitly as political actors. Given their agreement on the importance of stakeholders, the widespread ignorance and even outright rejection of consumer-based politics on the part of policy specialists is a puzzling contradiction." (Rhodes, 2005, pp. 4-7).
} 
It is not a coincidence that the United Nations has urged governments to adopt special policies that foster the creation of consumer organizations, to develop education and information programs for consumers and to establish quick, fair, low cost and affordable compensation mechanisms in the consumption relationships, especially for rural areas and low income sectors. According to the UN, consumer protection systems are essential to achieve a fair, equal and sustained economic and social development. ${ }^{14}$

Therefore, the organized participation of consumers, in addition to legitimizing the action of the authorities when duly listened to, balances the interests of all the parties in the industry, currently dominated by mega-companies present in many parts of the world.

\section{A. USA - FEDERAL COMMUNICATIONS COMMISSION - FCC.}

The Consumer Advisory Committee is part of the FCC. Its mission is to make recommendations and to facilitate the participation of consumers in proceedings before the Commission, mainly consumers living in rural areas, Native Americans and individuals with disabilities.

The Committee works mainly in the following areas:

1) Access for individuals with disabilities (for example, video description, closed captioning, readable bills, access to telecommunication products and services).

2) Consumer protection and information (for example, customer service, privacy, telemarketing abuses, services for minority groups and rural population).

3) Implementation of consumer participation rules in the FCC ruling process.

4) Impact of the new and emerging technologies (for example, broadband availability, digital television, cable television, satellite communications, low power FM radio and the convergence of these and other new technologies).

The Committee is appointed for a period of two years and must hold meetings at least twice a year. These meetings are open to the public and must be notified in advance in the Federal Register and adequate media. Meetings are broadcast via Internet. The FCC must provide the facilities and the human resources needed to hold the Committee meetings. The Committee members are not paid for their services, however, the FCC pays for the accommodation costs of the individuals with disabilities.

\footnotetext{
${ }^{14}$ United Nations General Assembly Resolution 39/248 of 16 April, 1985.
} 
The Committee members are appointed by the FCC Director and the Committee Director (also appointed by the FCC Director). The members must be recognized experts in each of the fields they represent, including but not limited to consumer defense organizations, minority groups, individuals with disabilities and rural populations representatives.

\section{B. UNITED KINGDOM - OFFICE OF COMMUNICATIONS - OFCOM.}

The Communications Act of 2003 requested OFCOM to organize a Consumer Panel to give advice on matters related to consumers' interests in the market it regulates, as well as special advisory committees that represent specific interests of some groups. The Consumer Panel is completely independent, it makes public its opinions and has its own budget to carry out the research it deems adequate.

The ten members of the Consumer Panel must be appointed by the OFCOM and approved by the Secretary of State. When appointing the members, the OFCOM must ensure the representation of interests of each one of the nations that make up the United Kingdom. In addition, OFCOM must guarantee that the panel gives advice on issues related to the interests of the following groups:

1) People living in rural areas.

2) People living in urban areas.

3) Small businesses.

4) People with disadvantages, people on low income and disabled individuals.

5) Elderly people.

In addition to the Consumer Panel, there are advisory committees that represent the specific interests of some groups. One of them is the elderly and disabled individuals' advisory committee, made up by eleven members appointed by OFCOM.

OFCOM also has advisory committees representing the nations that make up the United Kingdom (Scotland, North Ireland, Wales and England). The committee members are appointed by OFCOM through a process open to the public, ensuring that the members represent the interests and opinions of the regions.

\section{PERU - ORGANIZATION FOR THE SUPERVISION OF PRIVATE INVESTMENTS IN TELECOMMUNICATIONS - OSIPTEL}

In Peru, Act 28337 of July 232004 modified the organization of public utility regulators by adding the Users' Councils. Each regulatory agency was left to establish the structure, geographical distribution, members and proceedings to appoint or elect 
the members that make up the Users' Councils to ensure the effective participation of consumers and users associations, as well as the funding for the Users' Councils. The main tasks carried out by these Councils are:

1) To give opinions on the supervision, regulation, dispute resolution and answer to users' complaints tasks, which must be carried out by the regulatory agencies.

2) To participate in public hearings.

3) To organize academic events on regulatory issues.

4) To receive and submit before the Board of Directors consultations from users regarding policies and rules of the sector.

5) To propose action plans deemed adequate to improve the quality of the services.

\section{COLOMBIA - DEVELOPMENT AND SOCIAL CONTROL COMMITTEES.}

The Colombian Political Constitution (1991) includes the right of citizens to participate in the public services companies through the Development and Social Control Committees of Residential Public Services, made up by users or potential users of one or more public services.

The following are some of the functions the law assigns to the Development and Social Control Committees:

1) To propose to the residential public services companies plans and programs it deems necessary to solve the deficiencies in providing residential public services.

2) To try to obtain from the community the resources needed to expand or improve the residential public services, in conjunction with the residential public services companies and the municipalities.

3) To request the modification or amendment of the decisions adopted regarding residential stratification.

4) To study and analyze the amount of subsidies the municipality must offer from its budget to low income users, to examine the criteria and the distribution mechanisms of those subsidies, and to propose the measures needed for such distribution.

Each committee must choose a control member of the committee as a represen- 
tative before the public services companies and the competent authorities. Some of the control member functions are to train users on their rights and to help them make their complaints to the company. In addition, control members must look after the fulfillment of the company rules and assess its operation. They have the ability to ask the authorities to take the corresponding measures and the companies are forced to answer the requests made by the control member. Control members also take part in the Board of Directors of the companies, offering solutions to solve problems and fostering corrective actions to improve its operation, especially with respect to service provision and the relationship with the public.

\section{Regulator for the Poor}

The direct relationship between democracy and development shows that the most fair and equal societies are the ones in which citizens have access to political and economic decision making centers, through a legal system that guarantees the full exercise of their rights and the possibility of demanding accountability from the authorities for the trust deposited in them by the community. These statements are even more important when referring to poor people living in cities and rural areas. For them, the public sector - with all its structural deficits and problems - does not acknowledge their needs, and the lack of real solutions for the communities leads to an alarming and permanent social tension, which affects governability in our countries.

Therefore, it is necessary to create legal instruments that allow any person, specially those most in need, to participate in the decisions affecting them. Traditional legal and administrative proceedings are usually inadequate, untimely, little known and difficult to use by the poor.

For that purpose, users' associations should be created with State support, and the regulatory processes should be improved, making public hearings compulsory to foster everyone's participation, with explanations suited to all education levels. Similar measures can be applied when developing projects for community access, acknowledging the reality of benefited communities and allowing them to adopt solutions and becoming agents of change. These projects must be designed taking into account the needs of specific groups, along with their social, economic, cultural and ethnic characteristics. Therefore, it is necessary to take into account their opinions. Unfortunately, the participation of all interested parties when elaborating these projects has not been a formal, constant nor general practice. As a consequence, projects have design and execution errors, resulting in a loss of resources and efforts. In addition, it would be advisable to have a formal communication channel with the communities (e.g., Users' Committees) to assess the effects of the projects and to guide the 
population in the development of parallel processes (education, trade, greetings, work) in order to maximize the benefits and improve future projects.

Likewise, the possibility of introducing changes in the institutional organization of the authorities to include user representatives - as is the case in several countries with respect to television services - should be considered..$^{15}$ In this way, the prejudices against citizens' ability to responsibly discuss issues such as tariffs would be removed. In addition, it may be necessary to create new instruments to that effect, requesting that all decisions are correctly supported by studies that objectively analyze the potential impact of those decisions. These solutions may be accompanied by self-regulatory mechanisms such as the telecommunications ombudsman. Users may also be involved, and their functions may include more than just making recommendations and monitoring the policies implemented.

It is also important to have information systems that offer accurate data about users' needs and conditions, specially the poorest ones, with instruments that measure objectively the education level in relation to the service, their rights, the involvement in associations or committees, the answer given to users complaints (including the ones resulting from service refusal), the percentage of complaints with a positive outcome, and the most frequent complaints - with a special focus on the complaints coming from the poor.

In addition, companies should be compelled to communicate the users' rights, to establish proceedings so users may make suggestions, to assess the service provided and to come up with projects to improve the service and make it available to underserved groups. These proceedings may be supervised by users through the ombudsman, the consumers' committees and the regulators, imposing sanctions on the companies when the goals set by the regulator are not met. At the same time, there must be instruments in place to preserve the neutrality of the regulators in their decisions, avoiding the risk of being captured by the industry. Thus, it is necessary that authorities clearly explain the reasons for their decisions, so they may be controlled as well.

Of course, the design of this type of institutions is as difficult - or even more difficult - than the design of the regulators themselves, as many different aspects must be taken into account. Some of these aspects are the need to professionalize the

\footnotetext{
${ }^{15}$ Only a few countries in the world have organizations to protect the freedoms and rights related to media. In Latin America such organizations exist in Argentina, Chile, Ecuador and Colombia, but only in Colombia civil society organizations elect their members (one for the groups of parents associations and another for workers and actors union, while two members are appointed by the President of the Republic and the fifth member is elected among the representatives of the television regional public channels). In Chile the members are elected by common agreement between the Executive and Legislative Branches. In the rest of the countries, the members represent state institutions. It is of significant concern that the Armed Forces are sometimes involved in those entities.
} 
individuals representing consumers, to avoid that groups with other interests take control of consumer organizations, to guarantee that democratic processes are used in their creation, and to ensure that the regulation - including companies' control - is carried out in a clear and objective manner for all parties involved. If this is achieved, policy decisions are more likely to take into account both users' interests as well as those of the investors and, above all, the general interest. 


\section{References}

Ariño Ortiz, G. (2004). Privatizaciones y Liberalizaciones en España: Balance y Resultados (Privatizations and Business Liberalizations in Spain: Balance and Outcomes) (1996-2003). Granada: Comares.

Benetti Salgar, J. (2001). El Arbitraje en el Derecho Colombiano (Arbitration in Colombian Law). Bogotá: Temis.

Intven, H. (2000). Telecommunications Regulation Handbook. Washington, D.C.: InfoDev - The World Bank.

Jordana, J. \& Sancho, D. (2000). Reforma del Estado y Telecomunicaciones en América Latina (State Reform and Telecommunications in Latin America). Barcelona: Universitat Pompeu Fabra.

Kessides, I. (2004). Reforming Infrastructure - Privatization, Regulation and Competition. Washington D.C.: The World Bank. Retrieved from http://econ.worldbank.org/prr/ reforming_infrastructure/

Levy, B. \& Spiller, P.T. (1993). Regulation, Institutions and Commitment in Telecommunications: A Comparative Analysis of Five Country Studies. Washington, D.C.: The World Bank.

Perez Bustamante, L. (2004). Derechos del consumidor (Consumer's Rights). Buenos Aires: Astrea.

Rhodes, S. (2005). Social Movements and Free-Market Capitalism in Latin America: Telecommunications Privatization and the Rise of Consumer Protest. Manuscript.

Sampson, C. I. \& Spiller, P. T. (1994). Regulation, Institutions and Commitment: The Jamaican Telecommunications Sector. Washington D.C.: The World Bank.

Stiglitz, J.E. (2002). El Malestar en la Globalización (Globalization and Its Discontents). Madrid: Taurus. 
